HStud 25 (2011)2, 185-201 DOI: 10.1556/HStud.25.2011.2.2

\title{
THE AFTERLIFE OF SOLIDARITY: POLITICAL CONTESTATIONS IN POST-1989 POLAND
}

\author{
JACK BIELASIAK \\ Indiana University \\ Bloomington, IN, USA
}

\begin{abstract}
Poland's post-communist development is defined by economic and political progress, marred by divisive and unstable politics. An acrimonious political discourse, low levels of public participation, and chaotic politics appear in sharp contrast to a unified, engaged society of pre-1989. The reasons for the path lie in the nature of Poland's challenge to communism, the ethos of the opposition, and the expression of politics in normative value terms. Since 1989, attempts to appropriate the values of Solidarity as political capital have led to deep political divisions, first expressed in a post-communist divide between the former regime and the opposition, then in a post-Solidarity divide among heirs of the movement. The conflict over the legacy of Solidarity through the appropriation of its normative ethos for partisan politics distorts the values of collective will and social solidarity. The latest discourse pits the vision of "liberal Poland" dedicated to pluralist principles, individual rights and tolerance of differences to the vision of a "solidaristic Poland" dedicated to traditional, Christian and nationalist values. In these agendas, the symbolism of Solidarity serves as political capital to advance distinctive political futures.
\end{abstract}

Keywords: Solidarity, political values, post-communist, liberal Poland, solidaristic Poland

Poland's development over the past two decades is a paradox. On the one hand, the economic transformation and the political progress of the country are seen as a paradigmatic success story of post-communism. A devastated economy has given way to a strong market and consumer sector, and the institutional foundations of pluralism have replaced the communist monopoly of power. On the other hand, the country's accomplishments are marred by a divisive economy and unstable politics. Economic growth has occurred at the costs of deep regional and structural divisions, as between an urban, better off Poland A and a rural, poorer Poland B. An acrimonious discourse, low levels of public participation, and a chaotic political landscape characterize this political development. For many observers, most striking is the contrast between an active, cohesive society of pre-1989 and a passive, divisive society of post-1989. 
What explains an apparently successful democratic transition alongside resurgent illiberal and populist tendencies, the shift from an active civil society to a passive public, or the displacement of political solidarity with a fragmented political scene? The answers lie in the nature of the structural transformation experienced by the country over the 1989 divide, vested in the specific nature of Poland's challenge to the communist party-state, the organization of society during the transition, and the expression of politics along two distinct tracks - the politics of values and the politics of interests, located along two axes of political competition: a left-right continuum based on economic expressions, and a cultural space defined by identity claims.

\section{The Nature of Political Cleavages}

Specifically, it is the interface between the politics of interest and the politics of values that contribute to the paradoxical aspect of Poland's post-1989 democratic turn. During the initial years of the transition, the attempt to create a new political space defined by neoliberal economic and political policies depended on the emergence of group interests engaged in pluralist politics. This was a formidable undertaking throughout the post-communist space, as the shift from command economies, social suppressions, and political monopolies involved extensive, complex, simultaneous transformations resulting in extensive stress (Ost, 1993, 460-3). In the chaos and uncertainty of the transition, it was difficult for particular economic and social entities to realize what was in their interest. In such circumstances, the practice of pluralist politics was problematic. In Poland, the task was thwarted further by the persistence of strong ethical codes associated with the former division between Solidarity and the regime. It produced a dual political frame, superimposing the legacy of value politics upon the emergent political process concerned with interests (Bielasiak, 1992, 202-9). Since interests were ill defined, it became expedient to revert back to the politics of values as a currency of political discourse and practice.

In addition, the prevalence of political consensus around the Western model of development and accession to Europe reinforced the emphasis on value expressions. Given weak interests, political competition tended to revert to appeals about national and cultural identities. The overall effect was the intrusion into the formative democratic politics of norms derived from the past, translated into values and solidarities about the future (Horolets, 2006, 15-20). The consequence was the attempted appropriation of the Solidarity ethos for partisan politics in the post-1989 transition that distorted the values of collective will, social solidarity, and public trust represented by Solidarity's opposition to communist power. This

produced a world infused with normative commitments and the preservation of 
identities, first around a post-communist divide based on attitudes towards the former communist regime, then around an emerging post-Solidarity divide representing distinct visions of the new Poland. In both divides, politics is about substantive goals and moral judgments, and less about the procedural tenets of pluralist competition. Such a political language stands in contrast to a world defined by interests rooted in economic and social structures, competing over policy resources and the allocation of social and economic goods. I turn initially to a brief exploration of the causes behind the predominance of value politics in Poland, then to an examination of the expression of contested values in the post-communist and the post-Solidarity divides.

\section{The Struggle of Solidarność}

The politics of values can be traced to both the nature of the communist regime and the public struggle against its power during the period of late communism, expressed in a particular form in Poland. The structural underpinning of really existing socialism was its systemic politicization, i.e., the fusion of the economy, society and polity so that the expression of all interests was appropriated by the party-state. All decisions were subject to a litmus test by the ruling authorities, so that politics was not the interplay of different preferences but the imposed outcome of regime dictates (Marody, 1990, 259-61; Rychard, 1989, 178-84). Simply, interests were irrelevant to the politics of real existing socialism; instead, communism was depicted as a unitary formation devoid of group conflicts. While reality was far from vision, the system nonetheless deformed the identification and articulation of interests.

Empirical studies at the time describe a society whose political orientations are determined not by positions in the socioeconomic structure but by relationships to the communist state. Rather than class or occupation, what mattered was whether one was a member or not of the official party or trade-union (Adamski and Jasiewicz, 1989, 250-5). The attitudes of citizens were shaped foremost by connections to the regime, and thus defined politics in terms of ideological norms. The paradox of the really existing socialism was politicization without politics, which forced political life into the realm of values and identities around the communist-anticommunist divide (Bielasiak and Hicks, 1990, 497-9).

This had profound consequences for political participation. Citizens viewed engagement in the communist state as ritualistic, devoid of meanings and opportunities for the articulation of social, economic or political preferences (Marody, 1990, 263-6). Accordingly, politics was experienced as a set of reactions to ill-devised programs, taking the form of emotional responses to perceived injustices. True participation was not in the ritualistic confines of the party-state, in the ma- 
nipulated meetings, rallies, or elections, but was expressed through acts meant to redress the wrongful decisions through strikes, boycotts, or demonstrations. In turn, this dual participation fuelled a politics of identity characterized by alternative meanings, communities and norms. The official public sphere was reduced to a ritual, and led instead to the emergence of an alternative public space independent of the communist regime (Marody, 1990, 271). Politics took the form of a normative undertaking that had little to do with either the promise of class representation, or the expression of multiple voices in a pluralist process.

The second major factor in the prevalence of value politics was due to the very nature of opposition strategies and activities, especially its growing identification with the Solidarity movement in the 1980s. Solidarity emerged as a trade union to defend the interests of the workers, but it did so in close association with intellectuals that formed an opposition prior to the founding of the union. Solidarność came to embody the broad strata of Polish society in its defiance of communist power, and became infused with a strong unity ethos and collective will of the "real Poland" against the usurpation of the country's true identity (Kowalski, 1988). Expressed through powerful national symbols, the appeal of the movement as a unified force acting in the best interests of the country defined subsequent political currents throughout the decade and beyond (Kubik, 1994, 183-220).

The political world of the 1980s, therefore, was defined by the polarization of distinctive identities around society and regime. Again, many sociological studies reveal a strong impasse between "we" the nation, and "they" the party (Nowak, 1989; Jasiewicz, 1989, 250-5). Public opinion perceived social conflicts in terms of moral categories that took on political expressions, and were reflected in political behavior. State institutions and official acts were alien; those of the opposition, the Church or historical commemorations became the site of genuine, true political statements. In the struggle, the emphasis was on the formation of an alternative social and political space through the creation of an independent, autonomous civil society, brought about by ideals of social solidarity and independence (Bernhard, 1993, 131-50).

These expressions culminated in the development of a consensus ethos in Solidarity throughout the years of opposition that carried forth into the initial phase of the post-communist transition (Szwajcer, 1990). The consensus was built on the ideals of nation, solidarity, collectivity that achieved the status of powerful rhetorical symbols. This ethos tended to mask the many divisions that existed in the movement, whether around personalities, strategies, or political visions. The common struggle required cohesion. Even where differences emerged into the open, they tended to be couched in the language of Solidarity's values, and commitment to the mission of Poland's liberation. 


\section{The Return to Normal Politics}

The path from monopolistic to normal politics was beset with several roadblocks that contributed to the delay in the affirmation of interest politics rooted in a pluralist process and instead reinforced the tendency to express politics in terms of polarized values. A major impediment was the difficult structural adjustments in the Polish economy and society. The absence of well-defined socioeconomic interests paved the way to the fragmentation of Polish politics, since the absence of defined constituencies enabled the articulation of a multitude of political expressions. The splintering of the Solidarity movement enhanced the trend, as the big umbrella of Solidarność could not overcome the move from the "negative" task of overcoming communist power to the "positive" task of reconstructing Poland. The consequence was the appearance of a multitude of groupings, alliances, movements and parties in the post-communist political landscape (Kowalczyk and Sielski, 2004, 9-26). The confluence of these factors strengthened the proclivity to view politics as a struggle over values. Especially after the electoral victory of the former communists in 1993, values emerged as a powerful weapon of contestation to redress the political balance. One manifestation was a rhetoric bound with the normative divide between the "we" and the "they" of the pre-1989 period, transplanted into the post-1989 transition.

Thus the embrace of normal politics was problematic due to the very nature of the country's transformation. There was substantial confusion and uncertainty, for many people could not determine how the processes of marketization and democratization affected their future standing in society (Ost, 1993, 470-4). They faced considerable obstacles not only in the expression of preferences, but also in the very identification of their interests. In Poland, which embarked immediately on a strategy of economic shock therapy, the consequence was a highly fluid sociological picture. In turn, this problem exacerbated the political transition. The formation of a pluralist democracy is dependent of the actualization of social and economic interests that are well known and understood, and are integrated into political life through open expression of political demands (Dahl, 1983, 4-18; Kitschelt et al, 1999, 43-89). It is precisely the development of a pluralist system based on differences and on compromise that was at issue.

There were three primary impediments. One revolved around the aforementioned absence of interactions among interest groups, rooted in the socioeconomic structure, and defined by well-known preferences. Second, this situation was exacerbated by the absence of appropriate institutions to mediate emerging political differences (Bielasiak, 1992, 202; Ost, 1993, 456-9). Weak intermediary associations and institutions of representation were compounded by the necessity to de-mobilize large sectors of the population adversely affected by the neoliberal strategy of shock therapy. Third, the neoliberal consensus and the ensuing drive to 
marketization and Westernization undermined the capacity of diverse interests to stake out distinct positions. True, there were differences about the process and pace of accession, but the ideal of the return to Europe was a strong pull, and diffused the saliency of the issue. The dominant paradigm of a united Europe turned integration policies into a valence dimension of politics (Grzymala-Busse and Innes, 2003, 64-7) that reaffirmed the prevalence of values as a currency in the country's politics.

Clearly, then, the legacy of Solidarity as a movement defined by political cohesion and ethical commitment had a purpose for the transformation of the nation. For that reason, competing political sides appropriated the values of Solidarność to advance their own specific agendas, each proclaiming itself as the true heir of the Solidarity mantle (Wenzel, 1998, 143-6; Zubrzycki, 2001, 651-2). The past emerged as a battleground for the future, and in so doing facilitated the misinterpretation of Solidarity values for partisan gains.

The post-1989 political discourse was built around appropriating the legacy of Solidarność as an instrumental program that shaped the nature of the political course of the country. This first took the form of the well-known post-communist divide that characterized Poland's political scene in the aftermath of the 1989 revolution, and reflected the prior "we" the nation and "they" the regime divide as the primary cleavage of transitional politics. With the collapse of the post-communist left in the initial period of the new millennium, a new political schism assumed greater saliency in the political space of the country, rooted in appeals for public support by heirs of Solidarity who advocated different national platforms. This engineered a new "we" versus "we" Solidarity division in which the different political sides sought to employ the symbolism and legacy of the movement to capture the political landscape. At the time, the post-communist divide was displaced as the primary element of Polish politics in favor a more pronounced post-Solidarity cleavage.

The past once again served as the battleground for the future. The lineage of Solidarity provided considerable political capital in the on-going discourse. The various political tendencies emerging out of the movement had considerable interest in preserving the heritage of the past, precisely because it served as leverage in defining political fortunes. The different organizations, alliances, or parties that came into political life in the 1990s out of Solidarity's large oppositional umbrella claimed their status as the rightful successors to the movement of the 1980s. Their goal was to assume the moral authority of Solidarity in institutional and policy terms that appealed to society as a whole and represented all of Poland. The legacy of Solidarity was salient because it reverberated with the symbolism of defeating communism, freeing society from oppression, and propelling the nation towards independence. For politicians engaged in post-1989 politics, the capture of the 
symbol and language of Solidarity was a significant form of political capital providing considerable leverage.

\section{Evolving Political Contestations}

The importance of the normative discourse as the primary language in Polish politics was first reinforced by the political development of the 1990s decade, notably the electoral resurgence of the former communist party in the 1993 and 1995 elections, and the defeat of political forces associated with Solidarity, especially those on the right of the political spectrum. The fragmentation of Solidarity into multiple, competing political enclaves was in large part responsible for the turn in political fortunes so soon after the defeat of communism. The result was a significant political disequilibrium, with many forces associated with the former opposition frozen out of the corridors of power.

A concerted effort to remedy the situation led to a renewed restructuring of Polish politics in the late 1990 s, through the emergence of political actors previously relegated to the periphery. The earlier defeat at the polls created the need for the resurgence of a Solidarity backed political alternative. To that end, Solidarity became the primary agent in the formation of a broad political movement in June 1996, the Electoral Action Solidarity (AWS) (Wenzel, 1998, 142-6). In its founding declaration, AWS openly proclaimed its aim to unite diverse groups committed to a political agenda centered on truth and solidarity in order to form a truly independent Poland (Graniszewski, 1997, 59-65). At the time, a similar attempt to mobilize support on the basis of national traditions was carried forth by the Roman Catholic Church. Fearful that the post-communist agenda would lead to an erosion of Christian social positions, the Church moved to reassert its political weight by supporting the AWS initiative (Gowin, 1999).

On the other side of the political divide, a similar practice emerged. The former ruling communists moved to create a broad social democratic movement, the Left Democratic Alliance (Grzymala-Busse, 2002, 69-76). The 1993 parliamentary victory created the impetus to forge a left ruling coalition representing a diversity of actors united by a common political heritage rather than similar contemporary interests. The political identity of this grouping was bound to the "they" of the previous political epoch, as well as a current fear of an accounting with the past. It is evident that the institutional actors of the 1990s continued to reflect the old division in Polish politics between pro- and anti-communist regime forces. The identity of these movements was vested in their past actions and reflected the divisions of old, so that the political space signified the institutionalization of arrangements along inherited values. 
The ensuing political discourse reflected these divisions. In view of the political disequilibrium produced by the national elections in the early 1990s, the best option for the "we" side was to revert to the language of morality so as to question the identity of the emerging Poland. The net effect was to polarize Polish politics around the identities of "we" and "they," a division that echoed Polish history both distant and proximate. The disfranchised forces of the political right reached for this symbolism to reassert their legitimacy and regain a place at the political table. The task was to rebuild the former Solidarity ethos of freedom, dignity, and unity as a collective message, but now serving partisan needs. The values of national solidarity and of the true Poland were cast as a weapon of the political right against its political rivals, a reformulation that was appealing precisely because it echoed the values and struggles of the Polish people against communism. The infusion of these values as a currency of politics was manifest in a number of ways throughout the 1990s, first strongly tied to the post-communist divide, but culminating in a reformulated discourse that sought to use a similar language of values to establish a clear distinction between "Polska Liberalna" (Liberal Poland) and "Polska Solidarna" (Solidaristic Poland), especially in the electoral campaigns of the early 2000s (Jasiewicz, 2008, 9-12). The issues that came to embody the new political discourse cantered on the questions of national identity, decommunization, cultural and economic sovereignty, and the place of Poland in Europe.

Throughout the transition, then, politics gravitated towards a rhetoric that enhanced the prior emphasis on values and morals (Smolar, 1998). The prevailing concern with national identity took several forms. It surfaced into the open in the debates surrounding the adaptation of a new constitution, as evident in the political acrimony around the text of the 1997 constitution (Osiatynski, 1997, 66-72; Spiewak, 1997, 91-4). At the time, the version passed by the Sejm for approval by the citizenry was tied to the dominating parliamentary side, the political left coalition. For that very reason the extra-parliamentary opposition, supported by the Church, denounced the working version of the constitution. Instead, AWS and the Church favored another version that emphasized the cultural, religious and traditional identity of the Polish nation. The solution was the inclusion of two distinct views in the final draft, reflecting both preferences. Since neither side could give up its particular vision of the Polish state, the preamble incorporated the two visions side by side:

\footnotetext{
We, the Polish Nation - all citizens of the Republic, Both those who believe in God as the source of truth, justice, good and beauty, As well as those not sharing such faith but respecting those universal values as arising from other sources... Beholden to our ancestors for their labors, their struggle for independence achieved at great sacrifice, for our culture rooted in the Christian heritage of the Nation and in universal human values.
} 
The text reflects the two views, one of the Poland as the nation imbedded in Christian traditions, defining the very existence of the country through past struggles of the Polish people (Zubrzecki, 2001, 630-6). The other view asserts a civic understanding of the country, where citizenship is not a reflection of religious beliefs or nationalist traditions but universal and civic values. The two definitions of Poland found in the basic document are testimony to the saliency of the politics of identity and values.

The controversy over the Constitution proved to be a prelude to the political contestation that emerged in a few years, during the post-Solidarity divide. At that time, the political leadership of PiS guided by the Kaczynski brothers advocated a solidaristic vision that stressed a political community defined by cohesive, organic and exclusivist understandings of the nation. The emphasis was on social solidarity in contrast to liberal individualism, on confessional catholic culture wedded to pro-family values, a populist economic agenda to rectify inequalities, and a turn to Euroscepticism to assure Polish values in the face of European penetration. The alternative perspective, propagated by the Civic Platform program in response to the solidaristic rhetoric, stressed instead a civic vision of the political community based on pluralist political practices and individual rights.

Especially during the electoral campaigns for the parliamentary and presidential elections of 2005, the solidaristic side associated with PiS reinvigorated the language of value politics (Szczerbiak, 2008a, 421-9). The PiS leadership of the Kaczynskis accentuated the deformities associated with the Third Republic established after the collapse of communism in 1989 (Millard, 2008, 66-70). For them, the inequalities, corruption, and domination by powerful cliques with roots in the communist period were evidence of the collusion among nomenklatura and liberal elites that undermined the progress of the true Poland. It was thus essential to engage in a cleansing of the political landscape by dedication to the moral precepts of Christianity and normative traditional commitments that would restore the righteous path, embodied in the values of the Solidarity movement but undermined by the post-1989 political arrangements. In this manner, the political differences between PiS and PO, between solidaristic and liberal Poland, were linked to the legacy of Solidarity, to be used as leverage in the political contestation of 2005. A new political rhetoric emerged that sought to move beyond the post-communist power structures to advocate a new project, the Fourth Republic, appropriated by PiS for its own political gains (Markowski, 2006, 818-21). Above all, the Fourth Republic was to cleanse the sins of the past decade and establish a Poland rededicated to the ideals of nationalism, Christian morality, and popular will.

The position of "liberal" PO under the leadership of Donald Tusk was essentially a cautious response to the claims of its political rivals, rather than an overt attempt to articulate a strong alternative vision of Polish politics. Nonetheless, the strong solidaristic rhetoric of the electoral campaign forced the PO to react by de- 
nouncing the dogmatic positions of PiS and advocate instead a more moderate version of the political future (Markowski, 2008,1056-7). The basic message proclaimed the civic values associated with the past struggles of Solidarity, rather than the traditional and religious emphasis employed by the solidaristic side. Instead, the emphasis was on the fight for freedom and pluralism waged by the Solidarity movement in its opposition to the monolithic power of communism (Millard, 2008, 75). The idea was to link the "liberal" political program to a world defined by trust and cooperation, just as Solidarity was defined by consensus and tolerance. In essence, then, both sides of the post-solidarity divide sought to use the heritage of Solidarity to advance their own political fortunes, but reaching into the distinct values expressed by the opposition movement (Brier, 2009, 71).

The emerging alternative versions of the polity were evident in the resurgence of decommunization as a political issue. The earliest post-1989 attempt sought to remove the matter from the national political agenda. The first post-communist Prime Minister of Poland, Tadeusz Mazowiecki, initiated a policy of the "thick line" - a clear demarcation between past and present, preferring to look to the future rather than settle accounts with the past. But the thick line policy was never fully accepted by the entire political spectrum, and was denounced early on (Killingsworth, 2010, 277-9). The ensuing emphasis national identity in political discourse revived the saliency of the issue, and brought into sharp relief the question of settling accounts with the past. In the new millennium, concerns with the communists' role in the nation's history became once more a prominent political dispute, couched in the discourse of value politics. For the right, lustration was part of a moral indignation that targeted the continuing influence of the "reds" in Polish politics and society, and decommunization was equated with the salvation of the Polish nation (Wildstein, 2005, 203-19). Moreover, a new rhetorical stress was placed on a "red and pink" alliance aimed at associating the liberal political wing with the former communists, as exemplified by the Round Table Talks. While the negotiations had facilitated the transition away from communism and were recognized as such, the Round Table was increasingly depicted by the solidaristic establishment as a political collusion between ex-communist and liberal forces that betrayed the true nature of Poland (Wildstein, 2005, 34). For the secular left in particular, the lustration policy was a political witch-hunt designed to remove legitimate political opponents and impose a religious, nationalist cloak on the country.

Different versions of decommunization came to define the emerging post-Solidarity political contestation at the turn of the millennium. The predominance of conservative forces in the post-1997 Sejm, led to the passage of several acts and laws aimed at imposing a screening of the past, both trough condemnation of the communist era and the association of individuals with its regime. Decommunization was pursued through a series of legal actions that imposed further ver- 
ification on former communist officials, set-up a Screening Court for the lustration process, and created an Institute of National Remembrance to house communist secret police files and conduct investigations into former misdeeds (Horne, 2009, 352-9). Subsequently, in the post-solidarity divide, these steps led to a more systemic attempt to come to terms with the past, a reevaluation of communist period, and especially for assigning responsibility for past abuses associated with the communist period and the everlasting influence of the former nomenklatura (Shields, 2007, 169). In particular, Solidaristic Poland argued for the need to remove from positions of political and economic power the "uklad" (network), perceived as an organized conspiracy that took hold of the country's political process and economic development for its own profit, to the detriment of the country. Moreover, the network was depicted as an alliance that included former political adversaries, the elites of the communist establishment and the intellectual, liberal wing of the opposition, bent on a singular project to dominate the new Poland at costs to the values of the Polish people. The instruments to accomplish the essential purification involved a reinvigoration of the role of the IPN, whose investigations and publications of the names of (supposed) collaborators became a visible element in political life (Horne, 2009, 353). The process often led to the denunciation of well known opposition leaders as collaborators of the communist secret police, even tainting Lech Walesa as agent Bolek (Cenckiewicz and Gontarczyk, 2008). The aim of the solidaristic decommunization agenda was to cleanse Polish politics and commerce from the undue influence of the former communist apparatchiki and their liberal allies. To that end, when in power during 2006-07, the PiS Kaczynski government succeeded in passing a new lustration law that significantly expanded the scope of the decommunization process, requiring screening of public officials and professionals such as teachers and journalists, and expanding the meaning of collaboration (Killingsworth, 2010, 278-9). While the Constitutional Court subsequently declared the law unconstitutional, the episode reveals the intent of the solidaristic side to use lustration as a device for political purification and political gain. The agenda was further evident in the rhetoric of the 2007 electoral campaign, when the question of decommunization became a prominent issue with PiS appeals for the cleansing of the Polish political scene (Markowski, 2008, 1056).

Another contentious arena in the definition of what the country stood for concerned social and cultural understandings build around Christian and secular values. The discourse here was as intense, for Poland's true nature was defined by policies that enhanced or challenged the Christian traditions of the country (Beyer, 2007, 222-4; Brier, 2008, 70-5). In that respect, history and morality were once again played out on the political battlefield. In the solidaristic view, Poland's foundation rested on values linked to Christian faith and national expressions that were suppressed during the communist interlude, but now able to find 
renewed vigor. To the PiS establishment, this meant the need to encode those values in the legal framework and the practices of the new Poland. The social and cultural issues ranged across policies concerning the legal status of abortion, the content of family planning policy, the status of the death penalty, and tolerance of homosexuality. To reaffirm the traditional, Christian values of the country, the PiS leader Jaroslaw Kaczynski proposed in 2003 a new constitutional project to override the Third Republic's leftist-liberal order and replace it by a renewed Fourth Republic Poland guided by religious values and moral commitments (Shields, 2007, 169). The main idea behind the program was to restore the historical ties between Church and nation, to assure that the values embodied in that legacy serve as a guide to the Polish people as they rebuild a new post-communist Poland.

The claim was that the post-1989 liberal processes had led to the erosion of the Church's moral influence over society, and that it was essential to restore confessional values to maintain the moral integrity of society that was at the root of Solidarity's struggle to restore the true Poland. The social conservatism of the liberal center also produced identification with Christian mores, although the values of tolerance and inclusion were also part of its discourse, tied to the earlier Solidarity struggle against communist exclusion. The different emphasis was evident in practical polices, for example in regard to tolerance of a gay pride parade in Warsaw in May 2005. Lech Kaczynski, the mayor of the city at the time, described the proposed march as a moral affront to religious Poles and refused to grant the legal permit. PO's stance, despite its social conservatism, was to view the event within the constitutional rights of Polish citizens (Selinger, 2008, 20-6). The episode thus again reveals the critical distinction in the values emphasized by the political rivals, the religious and patriotic norms of the solidaristic vision contrasting with the civic and pluralist versions of the liberal side.

Similarly, the nature of the Polish nation was extended to the debate about international politics, and Poland's place in Europe. The earlier consensus that Poland belonged to the European tradition and therefore integration was the rightful path gave way to discord as the accession process into the European Union intensified in the new millennium (Machaj, 2006, 245-61). The actual entry of the country into the EU in 2003 brought forth questions about the status of Poland on the continent and the impact of European institutions and values on Polish traditions (Seleny, 2007, 161-3; Vermeersch, 2010, 504-7). The issue was brought to the surface by the "deepening" policies of the European Union, exemplified by the constitutional revisions proposed by the Lisbon Treaty. Certainly, both sides of the political discourse maintained that Poland was very much part of the larger Europe, but once again differences emerged as to the practical side of the relationship between Poland and Europe (Jasiecki, 2008, 372-7). 
Differences as to the sovereignty of Poland's values in the face of Europeanization, and the ensuing encroachment upon the traditional, religious commitments of the Polish people versus the secularized culture of the continent. For the political right, the struggle of Solidarity against communist power and Soviet influence was foremost about the restoration of Poland's independence in the world of nations and the affirmation of its true identity. This political struggle deserved recognition and preservation rather than displacement by a new form of political dependency (Vachudova, 2008, 866-8). Now, in the new millennium, the task was once more to safeguard the specific values of the Polish nation again the homogenization exemplified by the European culture that devalued the Christian and nationalist norms of the country. In this vain, the solidaristic political stance attributed to the liberal position an overcommitment to the Western process of modernization to the detriment of a Polish road, which was manifested in the decline of Polish sovereignty. Especially glaring for the solidaristic and populist forces was growing power of Poland's traditional European rivals, Germany and Russia (Reeves, 2010, 520-33). This attitude was clearly evident in the foreign policy of the Kaczynski government in the mid-2000s, which took a more aggressive stance towards the country's neighbors. Overall, the intent of the solidaristic camp was to depict its foreign policy as a continuation of the prior struggle for independence waged by the Solidarity movement against foreign domination, tied to Polish traditions and morality as an alternative path of development to either communism or liberalism.

The liberal voice rejected the critique as a tactical political ploy, especially since the attitude of PO remained committed to European integration, albeit emphasizing a "Europe of nations" as the preferred strategic development for the continent. For PiS, integration with European institutions and polices was a strong commitment. After the October 2007 elections, Prime Minister Tusk embarked on a policy that sought to improve the strained ties between Poland and the EU characteristic of the previous Kaczynski government. The Tusk administration also embarked on a new tactic that sought to remedy relations with its neighbors, to depict Poland as a reliable partner in the larger European enterprise (Szczerbiak, 2009, 2-3). Overall, the distinction between the attitudes of solidaristic and liberal Poland towards Europe can be characterized as different practical, tactical steps to the deepening agenda of integration, labeled respectively as "managed closing" and "managed opening" towards Europe.

\section{Conclusion}

In many ways, then, during the transition period, Polish political discourse evolved around the core issues of value and identity, whether in the context of 
constitutional, lustration, social or European policies. The political debate was shaped, and reshaped, by the extensive and often chaotic nature of the transformation that touched upon all aspects of the country's development - cultural, social, economic and political. The multiple, intense burden of transition contributed to a climate that sough to make sense of the profound changes through appeals to a political discourse based on a past ethos, immersed with morality and ideology (Smolar, 1998, 129-30). However, the infusion of a normative language of politics was not simply an escape from the politics of interests and the transformative socioeconomic reality. The language of values was no less real, and represented an attempt to reclaim a legacy of solidarity and commitment. For many, the struggle reflected echoes of the past around the former divide between "they" the state and "we" the people. For advocates of Solidaristic Poland, this meant foremost reclaiming Christian traditions, rejecting alien communist or liberal ideologies, and behaving according to moral strictures based on faith. For others, the revival of historical memory, of Christian faith, and an idealized political struggle as definitions of the new political identity signified too narrow an understanding of democratic politics, to be rectified through an expansion of civic, secular, and pluralist understandings.

Poland has experienced significant changes in the past two decades, the result of deep social and economic transformations, the accession to the European Union, and party system realignment. Together, these transformations altered significantly the political landscape of the country (Grabowska, 2004; Szczerbiak, 2008a). The new conditions produced the means to embrace a different form of political discourse build around clear group interests and devoid of the political confrontations rooted in the politics of values. Yet although the 2005 and 2007 elections produced major political realignments and the emergence of new dominant parties, the political rhetoric did not move away from the confrontation over the country's identity. Despite profound changes produced by the socioeconomic transformation, the integration into European structures, and party system consolidation, the contemporary political scene remains infused with a politics of values that invokes a past defined by the heritage of communism, the struggle of the opposition, and the post-communist and post-Solidarity divides forged in the 1989 event.

Indeed, what is most striking in the politics of the new millennium is the continuing dichotomy, the persistence of maximalist discourse, the contrasting visions of the country, as captured by the depiction of a contrasting Polska Liberalna (and Polska Solidarna). Liberal Poland is about the preservation of the Third Republic as the embodiment of democratic progress and the empowerment of citizens. Solidaristic Poland is about change from a Third Republic that has defiled the nation through compromise, individualism and universalism, to a Fourth Republic defined by tradition, community, and solidarity. 


\section{References}

Adamski, Wladyslaw and Krzysztof Jasiewicz (1989) 'Dynamika postaw kontestacyjnych' (Dynamics of contentious principles) in Wladyslaw Adamski, Krzysztof Jasiewicz, Lena Kolarska-Bobinska, Andrzej Rychard and Edmund Wnuk-Lipinski (eds) Polacy '88: Dynamika konfliktu a szanse reform (Poles '88: Dynamics of Conflict and Chances for Reform) (Warszawa: CPBP) 232-55.

Bernhard, Michael H. (1993) The Origins of Democratization in Poland: Workers, Intellectuals, and Oppositional Politics 1976-1980 (New York: Columbia UP).

Beyer, Gerald J. (2007) 'A Theoretical Appreciation of the Ethic of Solidarity in Poland. Twenty-Five Years After' Journal of Religious Ethics, Vol. 35, No. 2, 207-32.

Bielasiak, Jack (1992) 'The Dilemma of Political Interests in the Postcommunist Transition' in Walter D. Connor and Piotr Ploszajski (eds) (1992) Escape from Socialism: The Polish Route (Warsaw: IFiS Publishers) 199-216.

Bielasiak, Jack (2005) 'Party Competition in Emerging Democracies: Representation and Effectiveness in Post-Communism and Beyond' Democratization, Vol. 12, No. 3, 331-56.

Bielasiak, Jack (2006) 'Party Systems and EU Accession: Euroscepticism in East Europe' in Robert Rohrschneider and Stephen Whitefield (eds) (2006) Public Opinion, Party Competition, and the European Union in Post-Communist Europe (New York: Palgrave) 43-64.

Bielasiak, Jack and Barbara Hicks (1990) 'Solidarity's Self-Organization, the Crisis of Rationality and Legitimacy in Poland' East European Politics and Societies, Vol. 4, No. 3, 489-512.

Brier, Robert (2009) 'The Roots of the "Fourth Republic:" Solidarity's Cultural Legacy to Polish Politics' East European Politics and Societies, Vol. 23, No. 1, 63-85.

Cenckiewicz, Slawomir and Piotr Gontarczyk (2008) SB a Lech Walesa: Przyczynek do biografi (SB and Lech Walesa: Contribution to a Biography) (Warsaw: Instytut Pamièci Narodowej).

Dahl, Robert (1982) Dilemmas of Pluralist Democracy (New Haven: Yale UP).

Dudek, Antoni (2007) Historia Polityczna Polski 1989-2005 (Polish Political History 1989-2005) (Krakow: Arcana).

Garlicki, Andrzej (2004) Karuzela: Rzecz o Okraglym Stole (Carousel: Matter about the Round Table) (Warsaw: Czytelnik).

Gawin, Dariusz (ed.) (2002) Lekcja Sierpnia: Dziedictwo "Solidarnośći” po dwudzistu lat (The Lesson of August: The Heritage of "Solidarity" after Twenty Years) (Warsaw: IFiS PAN).

Gowin, Jaroslaw (1999) Kosciol w czasach wolności 1989-1999 (The Church in the Years of Freedom 1989-1999) (Krakow: Znak).

Grabowska, Miroslawa (2001) 'Partie i elektoraty' (Parties and Electorates) in Miroslawa Grabowska and Tadeusz Szawiel (eds) Budowanie Demokracji (The Building of Democracy) (Warsaw: PWN), 128-63.

Grabowska, Miroslawa (2004) Podzial postkommunistyczny: Spoleczne podstawy politiyki w Polsce po 1989 roku (The Postcommunist Divide: The Social Bases of Politics in Poland after 1989) (Warsaw: Scholar).

Graniszewski, Leszek (1997) 'Akcja Wyborcza Solidarność - Sojusz Prawicy Demokratycznej' (Electoral Action Solidarity - Alliance of the Democratic Right) in Stanislaw Gebethner (ed.) Wybory '97: Partie i programy wyborcze (Elections '97: Parties and Electoral Programs) (Warsaw: Elipsa), 59-85.

Grzymala-Busse, Anna (2002) Redeeming the Communist Past (Cambridge: Cambridge University Press).

Grzymala-Busse, Anna and Abby Innes (2003) 'Great Expectations: The EU and Domestic Political Competition in East Central Europe' East European Politics and Societies, Vol. 17, No. 1, 64-73. 
Halas, Elzbieta (2006) 'Symboliczna konstrukcja Solidarnośći: Konflikt interpretacji i politika pamieci' (The Symbolic Construction of Solidarity: Conflicts of Interpretation and the Politics of Memory) in Antoni Sulek (ed.) Solidarność: Wydarzenie, konsekwencje, pamiec (Solidarity: Events, Consequences, Memory) (Warsaw: IFiS PAN), 225-41.

Horne, Cynthia M. (2009) 'Late Lustration Programs in Romania and Poland: Supporting of Undermining Democratic Transitions?' Democratization, Vol. 16, No. 2, 344-76.

Horolets, Anna (2006) Obrazy Europy w Polskim dyskusie publicznym (Images of Europe in Polish Public Discourse) (Krakow: Universitas).

Jasiecki, Krzysztof(2008) ‘The Europeanization of Polish Democracy’ Polish Sociological Review, Vol. 164, 359-82.

Jasiewicz, Krzysztof (2008) 'The New Populism in Poland: The Usual Suspects?' Problems of Post-Communism, Vol. 55, No. 3, 7-25.

Killingsworth, Matt (2010) 'Lustration after Totalitarianism: Poland's Attempt to Reconcile with its Communist Past' Communsit and Post-Communist Studies, Vol. 43, No. 3, $275-84$.

Kitschelt, Herbert et al. (1999) Post-Communist Party Systems: Competition, Representation, and Inter-party Cooperation (Cambridge: Cambridge UP).

Kojder, Andrzej (1998) 'Systemic Transformation in Poland: 1989-1997' Polish Sociological Review, Vol. 3, 247-66.

Kowalczyk, Krzysztof and Jerzy Sielski (eds) (2004) Polskie partie i Ugrupowania Parlamentarne (Polish Parties and Parliamentary Groups) (Toruń: Wydawnictwo Adam Marszalek).

Kowalski, Sergiusz (1988) Solidarność a Polska (Solidarity and Poland) (Warsaw: Uniwersytet Warszawski).

Kubik, Jan (1994) The Power of Symbols against the Symbols of Power: The Rise of Solidarity and the Fall of Socialism in Poland (University Park, PA: Penn State UP).

Kubik, Jan and Amy Linch (2006) 'The Original Sin of Poland's Third Republic: Discounting "Solidarity” and its Consequences for Political Reconciliation' Polish Sociological Review, Vol. 153, 9-38.

Machaj, Lukasz (2006) Za i przeciw Europie (For and Against Europe) (Wrocław: Wydawnictwo Uniwersytetu).

Markowski, Radoslaw (2006) 'The Polish Election of 2005: Pure Chaos or Restructuring of the Party System' West European Politics, Vol. 29, No. 4, 814-32.

Markowski, Radoslaw (2008) 'The 2007 Polish Parliamentary Election: Some Structuring, Still a Lot of Chaos' West European Politics, Vol. 31, No. 5, 1055-68.

Marody, Mira (1990) 'Perceptions of Politics in Polish Society' Social Research, Vol. 57, No. 2, 257-74.

Marody, Mira (1997) 'Sens zbiorowy a stabilnosc i zmiana ladu spolecznego' (Collective Purpose and Stability and Change of the Social Order) in Mira Marody and Antonin Sulek (eds) Rzeczywistosc Polska a sposoby radzenia sobie z nia (Polish Reality and the Means to Cope with it) (Warsaw: Uniwersytet Warszawski).

McManus-Czubinska, Clare, William L. Miller, Radoslaw Markowski and Jacek Wasilewski (2003) 'Understanding Dual Identities in Poland' Political Studies, Vol. 51, 121-43.

Meardi, Guglielmo (2005) 'The Legacy of "Solidarity”: Class, Democracy, Culture and Subjectivity in the Polish Social Movement' Social Movement Studies, Vol. 4, No. 3, 261-80.

Millard, Francis (2006) 'Poland's Politics and the Travails of the Transition after 2001: The 2005 Elections' Europe-Asia Studies, Vol. 58, No. 7, 1007-31.

Millard, Francis 2008) 'Party Politics in Poland after the 2005 Elections' in Martin R. Myant and Terry Cox (eds) Reinventing Poland: Economic and Political Transformation and Evolving $\mathrm{Na}$ tional Identity (Florence, KY: Routledge), 65-81. 
Nowak, Stefan (1984) Spoleczenstwo Polskie czasu kryzysu (Polish Society at Times of Crisis) (Warsaw: Instytut Socjologii UW).

Osiatynski, Wiktor (1997) 'A Brief History of the Constitution' East European Constitutional Review, Vol. 6, Nos 2-3, 66-75.

Ost, David (1993) 'The Politics of Interest in Post-Communist East Europe' Theory and Society, Vol. 22, 453-86.

Ost, David (2005) The Defeat of Solidarity: Anger and Politics in Post-Communist Europe (Ithaca, NY: Cornell UP).

Rae, Gavin (2007) 'Back to the Future: The Resurgence of Poland's Conservative Right' Debatte, Vol. 15, No. 2, 221-32.

Reeves, Christopher (2010) 'Reopening the Wounds of History? The Foreign Policy of the 'Fourth' Polish Republic' Journal of Communist Studies and Transition Politics, Vol. 26, No. 4, 518-41.

Rychard, Andrzej (1987) Wladza i interesy w gospodarce (Authority and Interests in the Economy) (Warsaw: Uniwersytet Warszawski).

Seleny, Anna (2007) 'Communism's Many Legacies in East Central Europe' Journal of Democracy, Vol. 18, No. 3, 156-70.

Selinger, Marta (2008) 'Intolerance towards Gays and Lesbians in Poland' Human Rights Review, Vol. 9, No. 1, 15-27.

Shields, Stuart (2007) 'From Socialist Solidarity to Neo-populist Neoliberalization? The Paradoxes of Poland's Post-Communist Transition' Capital and Class, Vol. 93, 159-78.

Spiewak, Pawel (1997) 'The Battle for a Constitution' East European Constitutional Review, Vol. 6, Nos 2-3, 89-96.

Sulek, Antonii (ed.) (2006) Solidarność: Wydarzenie, konsekwencje, pamiec (Solidarity: Events, Consequences, Memory) (Warsaw: IFiS PAN).

Szczerbiak, Aleks (1999) 'Interests and Values: Polish Parties and their Electorates' Europe-Asia Studies, Vol. 51, No. 8, 1401-32.

Szczerbiak, Aleks (2008a) 'The Birth of a Bipolar Party System or a Referendum on a Polarizing Government? The October 2007 Polish Parliamentary Election' Journal of Communist Studies and Transition Politics, Vol. 24, No. 3, 415-43.

Szczerbiak, Aleks (2008b) 'Europe and the October 2007 Polish Parliamentary Election' EPERN Election Briefing, No. 37, 1-13.

Szczerbiak, Aleks (2009) 'The European Parliament Election in Poland, 7 June 2009' EPERN European Parliament Election Briefing, No. 36, 1-12.

Szwajcer, Pawel (1990) 'Paradox Solidarnośći’ Tygodnik Solidarność, 11 March.

Vachudova, Milada A. (2005) Europe Undivided: Democracy, Leverage, and Integration after Communism (Oxford: Oxford University Press).

Vachudova, Milada A. (2008) 'Tempered by the EU? Political Parties and Party Systems before and after Accession’ Journal of European Public Policy, Vol. 15, No. 6, 861-79.

Vermeersch, Peter (2010) 'Contesting Europe: Strategies and Legacies in Polish Political Competition’ Europe-Asia Studies, Vol. 62, No. 3, 503-22.

Wenzel, Michael (1998) 'Solidarity and Akcja Wyborcza "Solidarność": An Attempt at Reviving the Legend' Communist and Post-Communist Studies, Vol. 31, No. 2, 139-56.

Wildstein, Bronislaw 2005) Długi cień PRL-u: czyli, dekomunizacja ktorej nie było (The Long Shadow of Polish People's Republic: Or the Decomnunization that Wasn't) (Krakow: Arcana).

Zuba, Krzysztof (2009) 'Through the Looking Glass: The Attitude of Polish Political Parties toward the EU before and after Accession' Perspectives on European Politics and Society, Vol. 10, No. 3, 326-49.

Zubrzycki, Genevieve (2001) 'We, the Polish Nation: Ethnic and Civic Visions of Nationhood in Post-Communist Constitutional Debates' Theory and Society, Vol. 30, No. 5, 629-68. 